\title{
Jorge Amado in the USSR: allowed printed, "dangerous" on the big screen
}

Marina Darmaros ${ }^{*}$

\section{Introduction}

The present article aims at sketching a panorama of the screening and reception of film adaptations of Jorge Amado's works produced between the 1970s and 1980s and exhibited in the Soviet Union on different platforms and to analyze these choices.

To understand the context of these exhibitions, it is important to remember the filters that led to the entrance or not of Latin American cinema in the USSR. For VGIK researcher Tatiana Vetrova (2010: 536-545), the reason why Latin American cinema is little known to the Soviet public is intrinsically linked to the local distribution system and the policy of the foreign film purchasing commission "Soveksportfilm".

Up until the Perestroika period, there was no distribution in the country to "cinema clubs" or theaters specialized in art films to allow the purchase of movies in few copies for limited exhibitions. In addition, the use of cinema for political ends and lack of "emotive elements" made some of the main Latin American films unattractive to the Soviet viewer.

Vetrova repents that not many 1960's Brazilian classics of "Cinema Novo" - a movement that was worshiped by specialized Soviet publications of that time - did get in the Soviet theater distribution and highlights the fact that the biggest icon of this period, Glauber Rocha, has never had a place in the Russian-Soviet big screens. But the movement was well represented thought: in 1964, “O pagador de promessas" (1962, Anselmo Duarte);

\footnotetext{
* Marina Darmaros is a PhD candidate at the Department of Russian Literature and Culture of the University of São Paulo (USP). She was a researcher at the Filology Department of Moscow State University Lomonosov and holds a Master in International Journalism by Russian University of Peoples' Friendship. Currently she researches the connections between Brazilian writer Jorge Amado and the Soviet Union, with particular attention to the gatekeeping and the comparison of the Brazilian originals and its Russian translations. Contact: marinadarmaros@gmail.com
}

RRASILIANA- Journal for Brazilian Studies. Vol. 6, n.1 (December, 2017). ISSN 2245-4373. 
and in 1966, "Vidas Secas" (1963, Nelson Pereira dos Santos) e "Assalto ao trem pagador" (1962, Roberto Farias).

But, although nonexistent in the USSR until the 1960s, Brazilian production may have been more widely represented in Russian circuits in the period. In addition to the movies highlighted by Vetrova, the Internet Forum "Fenix"1 recalls a multitude of others that were dubbed by the main Soviet studios of the time (Górki, Soiuzmultifilm, Mosfilm, Lenfilm, Dovjenko): from 1961, "A Estrada" (1956, Oswaldo Sampaio), a drama with Adoniran Barbosa about a group of truck drivers who rebel against the opening of paved roads that will be occupied by big companies; in 1965, "Rio, 40 graus" (1955, Nelson Pereira dos Santos), a semi-documentary precursor of Cinema Novo about five boys from a favela in Rio de Janeiro; in 1974, "Em Família" (1970, Paulo Porto), on the difficulties of a common family in the liberal system which reigns in Brazil with regard to social welfare; in 1975, "Tati" (1973, Bruno Barreto), which tells the story of a pregnant single mother who moves with her 6year-old daughter from a poor neighborhood in Rio de Janeiro to Copacabana; and in 1976, "Jesuíno Brilhante, o cangaceiro" (1972, William Cobbett), based on the real story of the "cangaceiro" Jesuíno Brilhante, the film follows the life of the farmer who, due to the system, loses his lands and decides to form a wide faction of vigilantes.

In the "second wave of the new Latin American cinema", as Vetrova calls it, the Soviet theater distribution received, in 1983, "Coronel Delmiro Gouveia" (1979, Geraldo Sarno); in 1984, "O homem que virou suco" (1980, João Batista de Andrade); and in 1986, "Eles não usam blacktie" (1981, Leon Hirszman), which was selected for the competition of Moscow International Film Festival in that same year.

"Fenix" forum still recalls having been in the circuit, in 1983, "O casal" (1975, Daniel Filho), with Sonia Braga, about a couple dealing with the first conjugal difficulties, including an unexpected pregnancy and the professional problems that this will cause; in the same

\footnotetext{
${ }^{1}$ Avaliable at: fenixclub.com. The creator of the mentioned topic of discussion is the housewife and cinephile Liudmila (under the nickname "Salomeya8484"), who doesn't want to be identified and explained, corresponding with the author of this paper, that she gathered the complete list of dubbing done during the USSR and films in circuit of schedules searching "in magazines, movie directories, commented catalogs released during the USSR, that is, official sources. (...) This is the complete list of films shown in cinemas in the USSR (from 1955 to 1991). There may be two or three films missing in it, and some films have been dubbed and not released, or on the contrary suddenly went in the circuit, so they have not entered catalogs or annuals, but such cases, if any, are added to the list when we check their existence."
}

BRASILIANA- Journal for Brazilian Studies. Vol. 6, n.1 (December, 2017). ISSN 2245-4373. 
year, "O Grande Palhaço" (1980, William Cobbett), about a clown who leaves the circus leaving his son behind after his wife died in the trapeze; in 1984, "Amor e Traição" (1974, Pedro Camargo), about a rural worker that is used politically in Brazilian state of Piauí after killing his wife in the 1920s; in 1984, " Na estrada da vida " (1980, Nelson Pereira dos Santos), which tells the story of the singers Milionário and José Rico; in 1986, "Menino do Rio" (1981, Antonio Calmon), on the love between a surfer and a rich model and the social prejudice; in 1987, "Independência ou morte" (1972, Carlos Coimbra), a portrait of Dom Pedro I and the unsustainable political situation during his regency; in 1987, "Avaeté - semente da vingança " (1985, Zelito Viana), about a group of gunmen that decimates an entire Indian village to take possession of the lands.

\section{"Capitães de Areia", a Soviet cult icon}

Having sketched a general panorama of Brazilian cinema in the Soviet theatre distribution circuit, one can easily understand the tendencies that interested "Soveksportfilm", especially towards films that emphasized critiques on the liberal and capitalist systems, seen as decadent. Films that touched indigenous subjects, such as some Brazilian movies and many other Latin American ones, were also allowed in Soviet circuits and even in the so-called "closed cities"2.

These films reached a peak of popularity together with the "American western successors" (in Russian, "zameniteli amerikanskogo vesterna"), as were called the cowboy satires produced in the European socialist countries between 1966 and 1977. By then, USSR had already screened two original North American western films - "The Magnificent Seven" (1960) and "Mackenna's Gold" (1969) - and the apparatus tried to counter their enormous popularity with the same weapons.

Researcher Sergey Zhuk (2009), who investigated the cultural filters in the closed Ukrainian-Soviet city of Dniepropetrovsk through archives, interviews and analysis of local

\footnotetext{
${ }^{2}$ For more on Soviet closed cities, I highly recommend the documentary film "City 40" (2016, dir.: Samira Goetschel).
}

BRASILIANA- Journal for Brazilian Studies. Vol. 6, n.1 (December, 2017). ISSN 2245-4373. 
youth diaries between 1964 and 1982, wrote that for the "Soviet protectors of ideational purity", overall in a "closed city", the "indigenous" movies had an important ideological role. Above all, however, were the films produced by the East German studio Defa that "suggested to the Soviet viewer his own socialist alternative to such a popular western formula of 'bourgeois' cinema as the Hollywood western". But, as noted by Zhuk, the western films were not alone, and, contrary to what was to be expected, the realism critical to capitalism in an adaptation based on Jorge Amado's work also played a central role in the preoccupations of the ideologues of socialism:

Among the members of the Communist Party and KGB apparatus, the mass popularity of these [Western] American films was alarming and a sign of "dangerous imitation" of Western cultural forms among Soviet youth. The head of the KGB [in Dniepropetrovsk] noted that "three Western films caused a hysteria of emulations" among school and university students in Dniepropetrovsk. Two of those films were American - "Mackenna's Gold" and "The Sandpit Generals" - and another, British - "O Lucky Man!" (ZHUK 2009).

"The Sandpit Generals" (1971) was the only film based on a work of Jorge Amado that was allowed into theater distribution during the Soviet era. The American film adaptation directed by Hall Bartlet was shot in Bahia and appeared in 1974 in the Soviet big screens. It had a circulation of 1,201 copies, and was one of the record-holders during the Soviet era, with the 34th highest grossing among foreign films in USSR and the 100th highest grossing in the general estimate, which also includes national movies, according to data assembled by the critic and cinema professor Sergey Valentinovitch Kudriavtsev (KUDRIAVTSEV n.d.). "The Sandpit Generals" also entered the main competition of the 7th Moscow International Film Festival in 1971 (IMDB n.d.).

Also released in the USA as "The Defiant" or "The Wild Pack", the film never reached at home the success of the USSR. In the socialist country, the movie became so well-known 
that it inspired theater plays, books, special reports on post-Soviet criminal youth ${ }^{3}$, and even gang names in Ulan-Ude, in the Russian Far East (BADMAEV 2002: 93-97).

Also noteworthy is the fact that, when it achieved success in the USSR, the literary work of 1937 had not yet come out in Russian. "Capitães da Areia" was printed in the country for the first time only in 1976, split into two editions of the magazine Molodaia Gvardia - before that, only an 11-page excerpt had been published in the magazine "V zaschitu mira".

The film "The Sandpit Generals", in its enormous popularity between 1973 and 1975, received many complaints of the apparatus, contrary to what was expected, as shown by Zhuk in his case study in Dniepropetrovsk. The researcher mentions, for example, an interview with a local KGB retired officer who, in May 1991, states: “Our youth blindly imitated the antisocial role models of their favorite films' protagonists, American cowboys and young delinquents from 'The Sandpit Generals'”.

But it was precisely because of its criticism on the "capitalist way of life, doomed to suffering, crime and death of innocent street children" the film entered the contest of the Moscow festival in 1971, presented as "progressive" (ZORKI 1971, KAPRALOV 1972 apud ZHUK 2009).

In Dniepropetrovsk, the film was first screened in the cinemas in 1973, when it was the most popular movie in local cinemas for two months. With the success achieved, the local theater circuit management decided to keep the film's exhibits in the summer of 1974.

According to Zhuk, the diaries he surveyed, which belonged to teenagers between the ages of 14 and 15, showed an "unquenchable enthusiasm" for the film. He quotes the excerpt written by young local Alexandr Gussar on June 28, 1974: "I remember every scene of [Sandpit] Generals, but even so, I intend to watch the movie for the third time tomorrow, to remember the song from the movie".

\footnotetext{
3 One among many reports that were named after the book was the 1990's Piervi Kanal TV channel's "Generali gorodiskikh dzhunglei", based on "Generali pestchanikh karierov". Available in YouTube: https://www.youtube.com/watch?v=YxjiTloWIdo
}

BRASILIANA- Journal for Brazilian Studies. Vol. 6, n.1 (December, 2017). ISSN 2245-4373. 
Gussar's comment depicts the broad passion caused in viewers also by the song that opens the movie, by Dorival Caymmi, who comes to participate as a supporting actor in the film. Zhuk says that when the youth magazine 'Rovesnik' published the lyrics and notes of "The Sandpit Generals", many fans of the film tried to get the edition and to copy the Russian translation and score of song "Suíte do Pescador".

As journalist Sergey Komaritsin (2011) recalls, later the song gained new life with a Russian version ("Russian Theme Song Version for Sandpit Generals by Gruppa Neschastni Sluchai" n.d.) by the poet and musician Yuri Tseitlin. The contributor of the literary portal Stikhi, Marat Djumagaziev (2006) who analyzed its content, is critical though about the production:

Not aware of the song's lyrics in Portuguese, but impressed by the film, in the 1970s, jazz musician Yuri Tseitlin invented his own Russian sentimental variation for the now popular quartet "Akkord". In the late 1990s, the Brazilian melody with the text of Tseitlin was successful in giving new life to the group "Neschastni slutchai" (1997), and was sung by the protagonists of the famous novel "Brigada" (2002) and many others singers. But, in fact, the lyrics don't deal with abandoned children, but rather with fishermen who go to sea.

Therefore, the reception of the film was so overwhelming. But Zhuk reports that in Dniepropetrovsk, the movie was directly related to crime. According to police, 28,000 young people committed crimes per year - $72 \%$ of them were 25 years of age or older - and many of them said they identified themselves with the bad guys of "Mackenna's Gold" or "The Sandpit Generals". Officers also emphasized the "emotional factor" attributed to the soundtrack of "The Sandpit Generals" and the police complained about the spread of "foreign forms of fight and scuffle". According to them, many of the young criminals claimed to have been "The sandpit generals" their main source of information on the issue, also mentioning "capoeira", the Brazilian martial that combines dance, and acrobatics and music and was widely referred to after the release of the film.

BRASILIANA- Journal for Brazilian Studies. Vol. 6, n.1 (December, 2017). ISSN 2245-4373. 


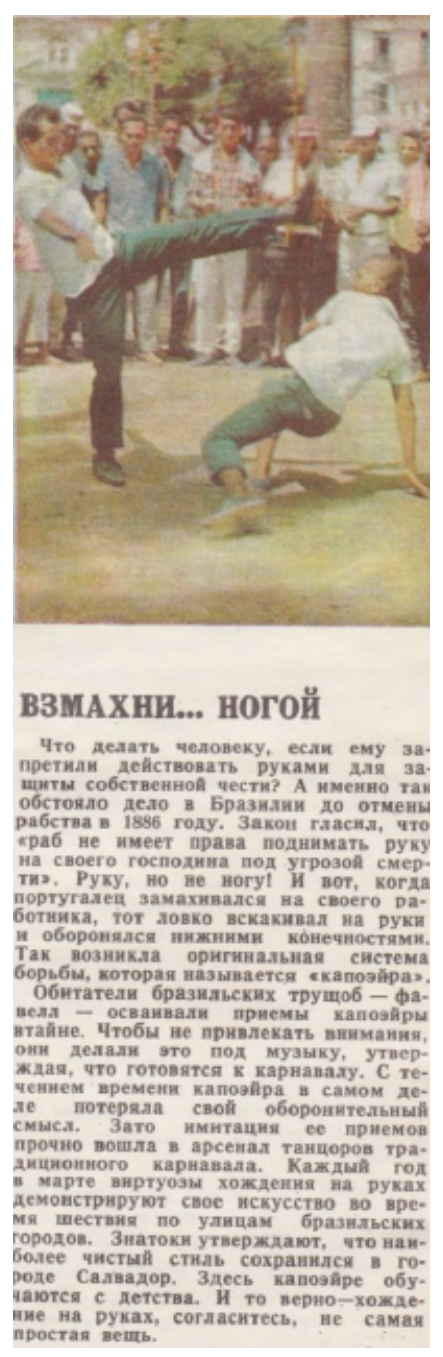

An article in the youth magazine 'Rosvenik' (Rosvenik 1974: 23) explains the 'capoeira' phenomenon to the readers.

Though the production had a bad reception by the apparatus, among spectators of the most diverse age groups it has become a myth ${ }^{4}$. Briefly speaking in the cinema and TV adaptations of the Amadian work, the researcher of the University of Cherepovets Elena Beliakova (BELIAKOVA 2010) asserts:

\footnotetext{
${ }^{4} \mathrm{BBC}$ wrote about this phenomenon a few years ago in a report:

http://www.bbc.com/portuguese/noticias/2012/08/120806_amado_capitaes_filme_tp.shtml
}

RRASILIANA- Journal for Brazilian Studies. Vol. 6, n.1 (December, 2017). ISSN 2245-4373. 
"The Sandpit Generals" has become part of our Russian mentality. The film is still watched now, for real, in video and on DVD. The very expression ${ }^{5}$ has become common: now the homeless of any country are only called this way. In general, this film about equity is considered "cult".

\section{"Dona Flor" and "Gabriela" ousted the theatre distribution}

Vetrova (2010: 536-545), examining the Latin American films that entered the theater distribution in the Soviet period, recalls the obstacle created by a supposedly erotic content in movies from that time, especially the Brazilian ones, and emphasizes, in this context, the Brazilian film adaptation of "Dona Flor and her two husbands":

For many years, during the purchase and selection of Latin American films for the major circuits, there were difficulties related to reception in our country due to severe limitations and prohibitions on the display of scenes of violence and sex on screen. In recent years, all this has been forgotten, but in immemorial times, these grounds were analyzed very seriously...

Thus, in many Latin American films, especially the Brazilian ones, explicit erotic scenes created obstacles for their exhibition in our country. For example, one of the biggest box office hits in Brazilian cinema, Bruno Barreto's film "Dona Flor and Her Two Husbands" (1976), based on the novel by renowned writer Jorge Amado, which was published several times in Russian, couldn't, by no means, be bought for theater distribution (at least until the early 1990's!) due to the "naturalism" in love scenes.

\footnotetext{
${ }^{5}$ The researcher refers to "The Sandpit Generals". This is justified by the fact that the Russian film was added by a sign - somewhat misleading - in the opening, which did not exist in the original American, which reads: "Millions of abandoned children roam the cities of South America. Every year, as the population grows, thousands children more appear on the streets.' (Los Angeles Times, May 24, 1970). In Brazil, these children have been known for generations as 'captains of the sand'."
} 
Therefore, it was no surprise that the most mainstream movies based on the Amado's works, "Dona Flor and her two husbands" (1976) and "Gabriela" (1983), both directed by the young Bruno Barreto, did not go through censors to enter the theater distribution circuit.

Officially, "Dona Flor and her two husbands" had no distribution to Russia, according to information I obtained from the archive of film producer LC Barreto. "Gabriela", on the other hand, although directed by Bruno Barreto, is a co-production of Sultana Corporation with Metro and UIP - United International Pictures. Both US companies, however, refuse to provide information on its distribution ${ }^{6}$.

Ousted from the theater distribution circuit and film festivals, "Gabriela", according to my researches in the TV schedule files of the newspaper Pravda between 1975 and 19967, was not broadcasted on TV as well, not even in the advanced hours when "Dona Flor" was showed during the Post-Soviet period, in 1994 and 1995 ${ }^{8}$. Pravda's television schedule archives between 1975 and 1996 show that, just like "Captains", "Gabriela" was not displayed on Russian-Soviet channels in the period (PRAVDA, n.d.).

Despite clear erotic censorship of the two titles, Zhuk recalls that even closed cities of the 1960s began to show on the circuit foreign films that contained nudity, according to a passage he rewrites from the 1970 diary of another Dnepropetrovski school student:

\footnotetext{
${ }^{6}$ In response to me by email in June 2016, MGM says: "It is not company policy to release proprietary information regarding its contracts and business activities. As a practical matter, to the extent, if any, that MGM still has any records relating to distribution of GABRIELA in Russia/USSR in the 1980's, those records are in a warehouse and would be extremely difficult to identify and locate. This would entail quite a project on our end and, aside from potential costs and time involved, we simply do not have the staff to conduct research that does not relate to immediate company business."

${ }^{7}$ The search was extended from 1975 to verify also the broadcasts of "The Sandpit Generals", which neither was shown on the Soviet TV in that period.

8 "Dona Flor" was broadcasted, according to Pravda, on December 9, 1994 at 10:30 p.m., on Piervi Canal and on March 3, 1995 at 11:40 p.m. on Canal Rossiya.
}

3RASILIANA- Journal for Brazilian Studies. Vol. 6, n.1 (December, 2017). ISSN 2245-4373. 
Today, I watched the film 'Bei Pervi, Freddi' (original title in Danish 'Slå først, Frede $\left.{ }^{19}\right)$ for the second time this year. How this comedy turned out to be funny! It has nothing to do with our flat movies. [...] And what a girl, the one Fred falls for! They show her naked! Of course she is dressed in a transparent outfit. But anyway, you can see her entire body on the screen...

However, "Dona Flor" and "Gabriela" - especially the latter - have stronger scenes of eroticism than those described in the Danish film, which made it even more difficult for them to be screened in the USSR and even written about in the Soviet periodicals.

But if there is no indication of Gabriela's public screening or broadcast before the Soviet collapse, "Dona Flor" was displayed in various circumstances in some regions of the Soviet Union, before being broadcast on Russian TV. One such occasion was the "Brazilian Film Week in the Soviet Union," which took place in 1981, as verified in an article in the newspaper “Sovietskaya kultura”(NOVIKOVA 1981: 7):

Yesterday, in Moscow, at the theater 'Udarnik', the Brazilian Film Week began in the Soviet Union, with the screening of the film 'Bye-bye, Brazil!'. The event, which represents an important stage in the development of cultural contacts between our countries, allows Soviet viewers to get to know many brilliant works by Brazilian filmmakers. Films by masters from the largest country in Latin America are shown in Moscow, Leningrad and Alma-Ata [Kazakhstan].

In an two-page article in Soviet magazine "Ekran" (BYKOVA 1981: 16-17), a paragraph devoted to "Dona Flor" highlights the positive aspects of the work:

${ }^{9}$ Note by the article's author.

BRASILIANA- Journal for Brazilian Studies. Vol. 6, n.1 (December, 2017). ISSN 2245-4373. 
The life of the protagonist [of the film 'Dona Flor'] is mysterious and enigmatic. In the background, popular melodies are heard; everything is covered by a veil of magic and spell. And, besides all this, this funny comedy is filmed in Brazilian-style, in a delicious and spicy way, with the atmosphere of the 1940s provincial life reconstructed in a precise way.

Tatiana Vetrova (1981: 163), on her turn, makes fun of the polemic "eroticism" of the film in a long, 12 pages, article about the festival for magazine "Iskusstvo kino":

Indeed, a viewer might consider, perhaps, that some scenes from the film are very explicit: but it's not worth it, my word!, to watch the movie aiming for great erotic malice in it.

Based on "cultural memory studies" or "collective memories"10, we can note that Vetrova's warning make sense on a Soviet context. Therefore, researching on several Internet-based Russian discussion forums and blogs on the subject, I noticed, for example, that the user nicknamed "Annassanta" (“Muzha, Dona Flor I Dva Ieio at RuTracker.org," n.d.) recalls, in a 2012 post in the Rutracker site, the general classification as porn that the film received:

The film is incredible, I watched it 25 years ago in the screenings of the international festival of Moscow in Leningrad. By then, it was considered to be porn! I am very grateful to this film and to Guy de Maupassant!

\footnotetext{
${ }^{10}$ These studies are highly valued today and well established in Germany, France and others, as the researchers of the University of Lund, in Sweden, recall: "It is widely recognized that social memory (or collective/cultural memory), understood as emotionally loaded and durable representations of the past, is widely used by and within social groups and plays an important role for their identities, expectations and actions. Issues of memory are nowadays on the political and cultural agendas of most countries" (TÖRNQUIST-PLEWA and BERNSAND 2012: 7).
} 
The user "Pipa2" (IBIDEM), in its turn, says that rumors that the movie had hot scenes did not fit the reality:

I remember very well to have watched the film before entering the Army, which I served between 1981 and 1983. I bought tickets for the theater "Baltika", for the Brazilian Film Festival. By the way, incidentally, I took the tickets to read the description of the movies (I saw the name of Jorge Amado) and the film, in my opinion it's okay, and there's no love scene at all, but humor and awkward times.

After the first session of "Dona Flor", there were rumors in the city about nudity and the crowd rushed to buy tickets, already all sold. In the recently established "Smena", in those days, an article came out discussing the film, and it was entitled "Corpses of Dona Flor". But no one forbade it, all the films of the festival, including this one, were screened at will in the cinemas until the end of the festival.

Other users, such as "Syslik2" (IBIDEM), recall in that same Internet forum that the movie content was, indeed considered as "porn":

The unforgettable 1976 was the decade [sic] of the Brazilian movies in Leningrad. I was standing there all day to get tickets to "Dona Flor" and didn't make it. That's how wild we were to see some erotical scenes...

"Mafia 536" (IBIDEM) has similar memories:

I remember our trip to the movies veery well. I was about 20 years old. After the screening, I remember above all the exit to the street: nobody could look to each other, men would turn their faces to the other side or stare the floor. 
Maybe someone here was in that crowd that was ashamed by the exit... Oh, youth!

The film was supposedly screened as well in the so-called "spetspokaz" ("special screenings"), with the entrance allowed only to the Soviet Union Communist Party members, according to a post by the blogger "Milaya_ochen" on the LiveJournal platform("Milaya Ochen at Live Journal," n.d.), and later, after the collapse of the USSR, it was distributed in video. The member of RuTracker "Gnom61" ("Muzha, Dona Flor I Dva Ieio at RuTracker.org," n.d.) comments the film in VHS and recall as well its screening in theaters during the 1980s, which produced anticommunist feelings in the spectators:

I have a VHS tape home with this film (bought at Gorbushka [market] around 1993), which I watched for the first time in 1978 in Leningrad at the Brazilian Film Week. [...] In the cinemas, people would stand up and say that there was no place for communists in the screening room.

\section{"Gabriela", an erotic bourgeoisie}

Jorge Amado sold the rights to the film adaptation of his book "Gabriela, Cravo e Canela" ("Gabriela, Clove and Cinnamon", 1958) as early as 1962 to Metro-Goldwyn-Mayer (MGM). But the film, which was released only in 1983, was never officially broadcasted in the Soviet Union. Given the context discussed earlier, its banishment is understandable: Gabriela's erotic scenes overwhelmed the toy penis with which Jose Wilker opens "Dona Flor" or the bare butt of Vadinho's ghost haunting his widow.

According to some viewers from that time, scenes of "Dona Flor" were also cut on television - which sometimes turned the film into an incomprehensible amount of scenes. However, Gabriela's adaptation has not only nude scenes, but also brief excerpts of sex. VCR 
had already begun to haunt official media in the $1970 \mathrm{~s}^{11}$, but only in the 2000s a voice-over copy made by one of the numerous forums dedicated to the free distribution of films in "Runet" started to run along the Internet.

Despite the lack of documents laying the groundwork for the banishment of the 1983 film on television or on the Russian theater circuit, I seek to relate the obstacles to the film to the main object of my $\mathrm{PhD}$ research, which are the filters for publication and the comparison of the original book "Gabriela, Cravo e Canela" (1958) in Portuguese and its first translation into English. It is well known that audiovisual works tend to suffer much more censorship than literary works because of their greater reach. Thus, the preoccupation caused in the late 1950s by the literary work can expose the apparatus mindset in the 1980s, when the film released.

Jorge Amado never properly lived in Moscow, but he had open doors to publish his works in the USSR, starting especially from his exile in Prague between the 1940s and 1950s, when he was an active member of the Communist Party. Natural from Bahia, he was one of the most widely read foreign writers in the USSR and an absolute exponent of the Latin American literature published there.

Amado's first publication in the USSR comes in the same year that he met Ilya Ehrenburg at the "World Congress of Intellectuals for Peace" in Wroclaw, Poland, in 1948, when he was already exiled in Paris. Two years later, already forced to leave France and living in Prague, he received the "Stalin Peace Prize" in 1951.

Though the Soviets began to publish Amado still in the 1940s, when his writing fit, in its own way, in the definition of "progressive literature", they did not stop it even with the turning point brought in 1958 by "Gabriela" - which is released only three years later in the USSR. And this happens in spite of the disappointing verdicts by the Soviet gatekeepers' literature commissions, as we will analyze in some cases based on documents that are

\footnotetext{
${ }^{11}$ Magazine "Sovietsky ekran" $n^{\circ} 10,1971$ (KOZNITSEV 1971), already brings articles discussing the subject, such as “A chto v kassete?" and "Kino doma - kakim ono budet?". Later on, this technology allowed a whole generation to have access to prohibited content - and part of them went into illegality by copying and selling this content, as the creator of the notorious Russian pyramid system MMM, Sergey Mavrodi, son of a video editor who was arrested for the first time in 1983 for producing illegal video recordings.
}

BRASILIANA- Journal for Brazilian Studies. Vol. 6, n.1 (December, 2017). ISSN 2245-4373. 
located in archives in modern Russia.

"Gabriela" was translated into Russian as early as 1961 in the Soviet Union, after a series of other Amado's titles, and marks the turning point in the author's work not only for leaving aside the focus on social issues and deepening in eroticism, but for placing a capitalist as the outsider hero who brings progress to a small town in Bahia. The change coincides with an important moment in Amado's life and in Soviet history: the four-year gap between Gabriela's publication and Amado's latest work in Brazil ("The Bowels of Liberty", 1954) is marked by the end of the personality cult promoted after Stalin's death in 1953 and by the secret speech given by Nikita Khrushchev at the 20th Congress of the Communist Party, in 1956, and the subsequent Amado's disillusionment and withdrawal from the Party ${ }^{12}$.

In the Soviet scenario prior to the title, important discussions were held to discuss the sensuality in Jorge Amado's work and its compatibility with what was conventionally called "progressive literature" in the USSR. Many of these meetings were of considerable importance, as so that they were shorthanded.

Thus, a stenography ("Stenogramma Zasedania Komissii Latino-Amerikanskikh Stran Soiuza Pissatelei SSSR Ot 8 Dekabria 1959 G.," n.d.: 4-5) of a Union of Writers Commission of Latin American Countries' meeting, dated as of December 8, 1959 and specifically focused on the discussion of the book "Gabriela, clove and cinnamon" shows the importance that Amado's literature - and mindset - "turning" had to Soviet intelligentsya at that point - and not only due to its exacerbated erotic. The document reveals concern and a possible influence of the discussion for the publication or not of the Amadian work - initially denied, but later acknowledged by the organizer of the discussion in the Latin American Commission of the Union of Soviet Writers, Spanish translator Elena Mikhailovna Kolchina:

Taking into account the whole content of Latin American literature, there was the urgent need to bring together the Latin Americanists of Moscow and elaborate their point of view on this work ["Gabriela"]. No one has put

\footnotetext{
12 After rumors generated by the secret speech, Amado even publishes a letter, on October 11, 1956, in Prensa Popular newspaper in which he states that he feels "surrounded by blood and mud" (PERALVA 1962: 186).
}

BRASILIANA- Journal for Brazilian Studies. Vol. 6, n.1 (December, 2017). ISSN 2245-4373. 
the question of if someone will speak for or against. The matter is what this book stands for.

We've known Jorge Amado for a long time, maybe it's our second decade with him. We love him very much, we cherish him greatly; his role in social life in Brazil, as always, is great, and, as always, he continues to be our friend. But this book differs from all his work. And the purpose of our meeting is to elaborate our point of view.

[...]

This does not mean that we will or won't recommend the translation of the book, and no one has belittled the opinion of the group [...]

The organizer is then questioned by another participant in the discussion, "tovarish Bazarian", nickname for Jacob Sagh Bazarian, a Brazilian-Armenian philosopher who was elected Soviet deputy by Armenian Republic: "I am not from this area, but I know that it is the first time that a book, in the case of Jorge Amado, has been previously discussed" (IBIDEM: 5).

The discussion continues, and Kolchina contradicts her first statements. "This book leads us not only in the Soviet Union to reflect, but in Brazil itself, and in Romania, in Germany (...) I give myself the freedom to remember that, even though we are a very powerful commission, this commission doesn't have a social character. We are not a commission under some organization that will decree the publication or not [of "Gabriela"], but we can recommend it or not (...) If we were talking about a writer of second or third category, then it wouldn't matter, but in relation to Jorge Amado, our friend, we must deal with it very cautiously, align a point of view and say whether or not it is worth publishing this book, or perhaps publishing it with some preface."

The talk then takes place in a complicated way with the seven participants (among them three translators of Amado: Vera Kuteischikova, Nadezhda Tultchinksaia and Yuri Kalugin, as well as Yuri Dashkevich, who turns to be later the elaborator of Gabriela's preface in 1961) avoiding to start entrusting their opinions about the book and talking about "advocating" about it. Kalugin then recalls (IBIDEM: 24): "I have translated four books of 
Amado, and none of them have been discussed." After more negatives of the participants express themselves on the book, Kolchina (IBIDEM: 26), after stating that it was "good that this meeting be shorthand, and the opinions of all registered" and that (1959: 30) "Jorge Amado is a true Communist, and there is no need to raise doubts about Jorge Amado", finally reaches the point (IBIDEM: 31):

Here's the content. A bourgeois arrives at a backwater town, the town becomes capitalist and, thanks to his efforts, begins to flourish. And even morality triumphs, because beforehand a husband who killed his wife was not considered a criminal, and then they start to consider it a crime and send such men to prison. This is what raises doubts in me.

Kalugin, who by then had already expressed (1959: 27) that "[Gabriela,] like any other book has grounds for raising the question (...) that the book is harmful (...)", says that "whoever wants to cast the first stone, let him cast, for all who have read this book are impressed with it." And then he refutes Kolchina's statement, stating (1959: 31) not to think that Amado wanted to "chase a political line" with "Gabriela".

"Even so, the fact that the bourgeoisie has brought the flowering to that city exists," Kolchina says (IBIDEM: 32), and the discussion continues, taking a comical tone for those who follow it in the present time. Kalugin (IBIDEM: 32) says that "It must be taken into account that capitalism is also progressive in relation to feudalism." Kolchina (IBIDEM: 32) then criticizes Gabriela because she "marries a merchant and is very satisfied with it." Tovarish Bazarian (IBIDEM: 35-36) refutes it by suggesting that historians and philosophers should be included in the discussion and stating that "this happens in 1926, when the bourgeoisie had a more progressive role and, if Gabriela didn't marry a Communist, this may have happened because at that time there were very few communists." He, as others, claims that not to publish Amado's work would offend the Brazilian author, but recalls (IBIDEM: 37) that "he himself said that he is an intellectual of the petty bourgeoisie and repeated Lenin's words about Gorky. He made such a parallel."

Several participants also recall words that would have been uttered by Brazilian 
communist Luis Carlos Prestes - and there they mention various occasions, without reaching a consensus - in defense of the Amado's work, remembering, as Bazarian did, that "he [Amado] is a true friend of the party and friend of the Soviet Union". The friendship with Amado and with Prestes - would be one of the reasons for which it would be worth to publish "Gabriela". The Soviet spy and translator Nadezhda Tultchinskaia is the only one who keeps against the publication until the end of the discussion.

The Latin Americanist Vera Kuteischikova, on the other hand, stands favorably to it because, she says, the refining of the Amadian work has reached its climax with the elements of national identity mixed with realism. But she warns (IBIDEM: 48) that "of course something may shock us, there are many erotic scenes, but they were also in previous works".

Dashkevich defends the publication as well, but recalls (IBIDEM: 52): "I read the work of a man who had an extremely complicated political turmoil both in relation to Pasternak as to Hungary. But this was his first work after these turbulences." He recalls (IBIDEM: 53-54) that his magazine "Inostrannaia Literatura" found it necessary to inform the reader about the new work and the response of the public was colossal, with letters flooding the newsroom to demand the publication of "Gabriela".

Another factor that bothers and to which Kolchina refers (IBIDEM: 55) is that Amado, as she stated earlier, leaves the pessimistic realism, but then goes for a happy ending "in the union with the bourgeoisie, in the peace with the bourgeoisie." She also referred to the Hungarian issue, Pasternak and the creation of the magazine "Para Todos". The discussion, which extends over more than 60 shorthand pages, shifts then the importance from anything else to the colonel's electoral campaign against the liberals, and is finished up with the "Rinoceronte Cacareco", a rhinoceros that was actually elected as a city councilman in São Paulo in October that same year.

After all, "Gabriela, clove and cinnamon" is published in the Soviet Union in 1961, as already described, translated by Kalugin and with a preface by Dashkevich. It brings some ideological cuts and the cushioning of eroticism. A sign of the thaw period, the publication seems to draw a parallel with the work: as well as what Amado called "progress" - for Kolchina, "capitalist flourishing" -, which reached Ilheus and quelled the colonels, who no longer killed their unfaithful wives, the USSR no longer banished, as it had done before with

3RASILIANA- Journal for Brazilian Studies. Vol. 6, n.1 (December, 2017). ISSN 2245-4373. 
foreign writers such as Howard Fast, those who went against the interests of the party in literature. But not in the movies.

\section{References}

AMADO, Jorge. Gabriela, Cravo e Canela. São Paulo: Livraria Martins Editora, 1960.

AMADO, Jorge. Gabriela (khronika ognogo provintsialnogo goroda). Moscou: Izdatelstvo inastannoi literaturi, 1961.

BADMAEV, Andrei. 2002. “Neformalnie Molodiojnie Assotsiatsii v Ulan-Ude." Vestnik Evrazii, 90-104. http://eavest.ru/biblioteka/stati-i-knigi/regiony/43-andrej-badmaevneformalnye-molodezhnye-assotsiatsii-v-ulan-ude.

BELIAKOVA, Elena. 2010. Russki Amadu I Brazilskaia Literatura v Rossii. Moscow: ILA-RAN.

BYKOVA, Irina. 1981. “Po Dorogam Brazilii.” Sovietsky Ekran, 1981.

DZHUMAGAZIEV, Marat. 2006. “Pesnya Iz kinofilma 'Generali Peschanikh Karierov', Brazilia - SShA." Stihi.ru. 2006. http://www.stihi.ru/2006/11/05-1261.

IMDB. n.d. "1971 Moscow International Film Festival." Accessed June 15, 2016. http://www.imdb.com/event/ev0000450/1971.

KOMARITSYN, Sergey. 2011. “Kommunist Na Karnavale." Gorodskie Novosti, November 4, 2011. http://www.gornovosti.ru/tema/history/kommunist-na-karnavale.htm.

KOZNITSEV, Grigory. 1971. “A Chto v Kassete?” Sovietsky Ekran, 1971.

KUDRIAVTSEV, Serguey Valentínovitch. n.d. "Zarubezhnie Filmi v Sovietskom Kinoprokate." Accessed May 3, 2016. http://kinanet.livejournal.com/13882.html\#cutid1.

MARTYNOVA, Tamara. Neuzhto o liubvi vse skazano? Pravda, januray, 31st, 1996, N 15 (27661), p.4.

“Milaya Ochen at Live Journal." n.d. http://milaya- 
ochen.livejournal.com/76115.htmlgrazy_gunner.

“Muzha, Dona Flor I Dva Ieio at RuTracker.org." n.d. https://rutracker.org/forum/viewtopic.php?t=708856\&start=30.

NOVIKOVA, L. 1981. “Brazilski Kinomarafon.” Sovietskaya Kultura, 1981.

PAPPON, Thomas. Obscura adaptação de 'Capitães da Areia' para o cinema marcou geração russa.

http://www.bbc.com/portuguese/noticias/2012/08/120806_amado_capitaes_filme_tp.shtml

PERALVA, Osvaldo. 1962. O Retrato: Impressionante Depoimento Sobre O Comunismo No Brasil. Rio de Janeiro: Editora Globo.

Pravda.n.d. "“Televidenie' (Soviet TV Schedule Pages in the Daily newspaper 'Pravda' from 1975-2000)."

Rosvenik. 1974. “Bzmakhi... Nogoy," 1974.

"Russian Theme Song Version for Sandpit Generals by Gruppa Neschastni Sluchai." n.d. Accessed June 15, 2016. https://www.youtube.com/watch?v=r3Ee3FHPbss.

TÖRNQUIST-PLEWA, Barbara, and BERNSAND Niklas. 2012. "Painful Pasts and Useful Memories: Remembering and Forgetting in Europe. CFE Conference Papers Series No. 5." Lund.

VETROVA, Tatiana. 1981. “Trudnoie Vozrozhdenie.” Iskusstvo Kino, 1981.

. 2010. "Publika Aplodiruet." In Kinematograf Latinskoi Ameriki. Versha Svoiu Sudbu. Moscou: Izdatelstvo Kanon-Plius Reabilitatsya.

ZHUK, Sergey. 2009. “ZAPAD V SOVETSKOM 'ZAKRYTOM' GORODE: 'chuzhoe' kino, Ideologiia I Problemy Kul'turnoi' Identichnosti Na Ukraine v Brezhnevskuiu E'pokhu (1964-1982 Gody)." Novoe Literaturnoe Obozrenie 6. Moscow:548-65.

Archival documents

"Stenogramma Zasedania Komissii Latino-Amerikanskikh Stran Soiuza Pissatelei SSSR Ot 8 Dekabria 1959 G." Russian State Archives of Literature (RGALI). Fond: 631, opis 26, ed. khr. 4471. December 8, 1959. 62 pages. 
"Stenogramma zasedania v Inostrannoi komissii po obsujdeniu stati V.N. Kuteischivova 'Jorge Amado' dlia sbórnika 'Progressívnaia literatura Latínskoi Amériki." Russian State Archives of Literature (RGALI). Fond: 631, opis 26, ed. khr. 4451. June 7, 1954. 18 pages. 